\title{
34. ORGANIC GEOCHEMICAL CHARACTER OF SELECTED CORES, DEEP SEA DRILLING PROJECT HOLE 530A ${ }^{1}$
}

\author{
Barry Jay Katz, Bellaire Research Laboratories, Texaco Inc., Bellaire, Texas
}

\begin{abstract}
The Albian/Cenomanian strata in Hole 530A are organically richer than are the post-Cenomanian strata. Organic matter is thermally immature and appears to be of dominantly marine origin with either variable levels of oxidation or variable amounts of terrestrial input. Geochemical data alone cannot establish whether the black shales present in Hole $530 \mathrm{~A}$ represent deposition within a stagnant basin or within an expanded oxygen-minimum layer.
\end{abstract}

\section{INTRODUCTION}

A principal objective of Deep Sea Drilling Project (DSDP) Site 530 was to provide information on the paleo-oceanographic evolution of the Angola Basin so that the origin of the middle to Late Cretaceous black shales previously recovered at Site 364 could be further defined. At Site 530 over 250 organic-rich black shale beds of Albian to Coniacian age are interbedded within a red and green claystone sequence of turbidite origin. These organic-rich horizons are time-equivalent to similar beds at Site 364. The remaining Cretaceous strata are dominated by other debris flow deposits, including clastic limestones, and lack the black shale strata.

One of the methods used to decipher the evolution of the basin was to study the sedimentary organic matter. This chapter is one of a series which describes the type and quantity of organic matter within Hole 530A. The type and quantity of organic matter preserved in a given area are controlled by such factors as: biologic productivity, mode and distance of transport, sedimentation rate, and biochemical demand (Demaison and Moore, 1980 ). Based on both physical and chemical properties four principal types of sedimentary organic matter can be recognized (Tissot et al., 1974): type I (lacustrine origin), typical of oil shales and boghead coals; type II (marine origin), deposited under reducing conditions; type III (continental origin), derived from higher plants; and type IV, recycled or residual organic matter (or R.O.M.).

Tissot et al. (1979, 1980) have noted that organic matter of types II, III, and IV have been recognized in Cretaceous strata of the Atlantic basins. Type II is characterized, in immature sediment, by high atomic H/C and moderate atomic $\mathrm{O} / \mathrm{C}$ ratios and by high total extractable and pyrolytic hydrocarbon yields relative to organic carbon content. This material has good potential for the generation of oil upon thermal maturation. Immature type III organic matter is characterized by low to moderate atomic $\mathrm{H} / \mathrm{C}$ and moderate to high atomic

\footnotetext{
${ }^{1}$ Hay, w. W., Sibuet, J.-C., et al., Init. Repts. DSDP, 75: Washington (U.S. Govt. Printing Office).
}

$\mathrm{O} / \mathrm{C}$ ratios and by low total extractable and pyrolytic hydrocarbon yields relative to organic carbon content. This material will typically generate gaseous hydrocarbons with minor amounts of liquids upon thermal maturation. Type IV organic matter, derived from previously sedimented deposits, has typically undergone either severe thermal stress or oxidation. Therefore, this material has very low atomic $\mathrm{H} / \mathrm{C}$ ratios and may exhibit highly variable $\mathrm{O} / \mathrm{C}$ ratios. It has very low total extractable and pyrolytic hydrocarbon yields relative to organic carbon content. Type IV organic matter is no longer capable of generating hydrocarbons.

In this chapter, we have attempted to characterize the organic matter through use of pyrolysis assay and analysis of both soluble (bitumen) and insoluble (kerogen) components.

\section{ANALYTICAL METHODOLOGY}

Thirteen samples of $\sim 50 \mathrm{~g}$ each were obtained from the frozen organic geochemistry core collection. Their selection was based on organic carbon data supplied by Dr. B. Simoneit (Chairman, Organic Geochemistry Panel). Their stratigraphic positions are summarized in Figure 1. Each of the samples was oven-dried at $60^{\circ} \mathrm{C}$ and ground to $\sim 325$ mesh. The organic carbon content $\left(\mathrm{C}_{\mathrm{org}}\right)$ was determined on each sample using a LECO combustion system after decarbonating. Those samples with organic carbon contents $\geq 0.5$ wt. \% were subjected to pyrolysis assay using a Rock-Eval system as described by Espitalié et al. (1977).

The kerogen in each of these samples was isolated for elemental analysis (C, H, O, and $\mathrm{N})$. In addition, a portion of each of these samples was extracted using an azeotropic mixture of methanol, acetone, and chloroform, deasphaltened with pentane, and fractionated using liquid chromatography.

\section{ANALYTICAL RESULTS}

\section{Organic Carbon}

The organic carbon contents of the 13 samples examined ranged from $0.01 \mathrm{wt} . \%$ to $2.27 \mathrm{wt} . \%$ (Table 1). The organically richest samples were from Albian and Cenomanian strata. Samples from these strata, with the exception of Section 530A-99-5, contain above-average quantities of organic carbon $\left(>0.3 \mathrm{wt} . \% \mathrm{C}_{\text {org }}\right.$ ) relative to the DSDP data base (McIver, 1975). The post-Cenomanian samples and Section 530A-99-5 contain belowaverage quantities of organic carbon relative to the same data base. 


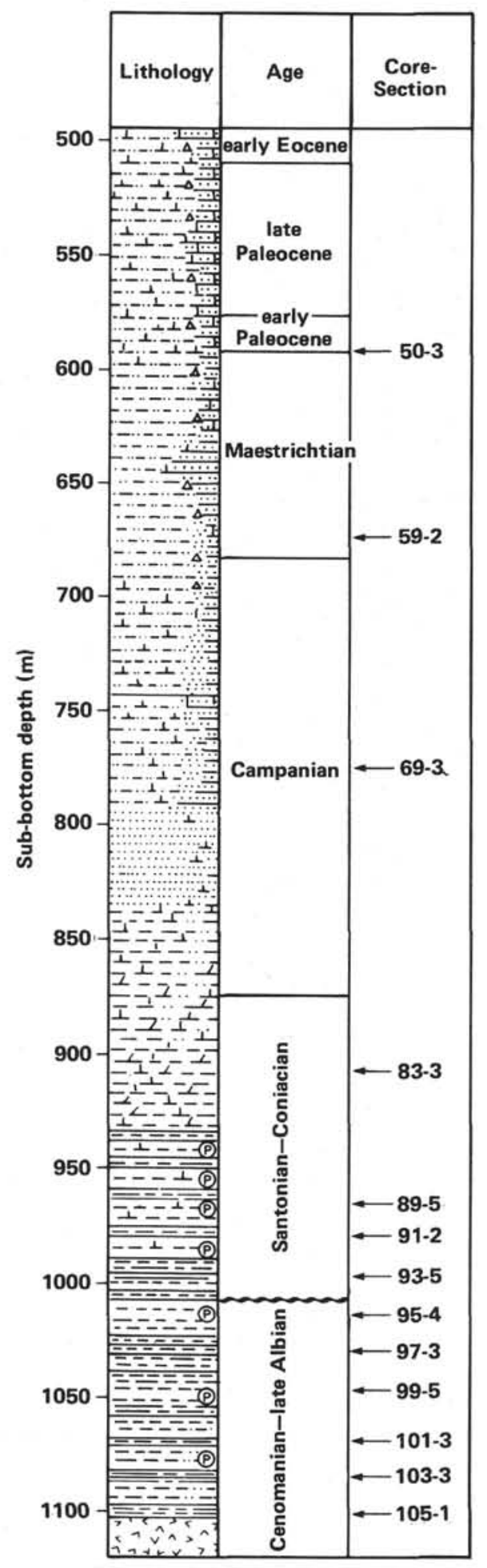

Figure 1. Partial stratigraphic summary of Hole 530A including positions of samples used in this study. (Revisions of stratigraphic ages are given in Steinmetz et al., this volume.)

\section{Rock-Eval Pyrolysis}

Pyrolysis assay was limited to the four samples with above-average organic enrichment. These results are also summarized in Table 1. The total hydrocarbon (HC) yields $\left(\mathrm{S}_{1}+\mathrm{S}_{2}\right.$; distillable $\mathrm{HC}+$ generatable $\left.\mathrm{HC}\right)$ ranged
Table 1. Organic carbon and pyrolysis assay, Hole 530A.

\begin{tabular}{|c|c|c|c|c|c|c|c|c|}
\hline \multirow{2}{*}{$\begin{array}{c}\text { Sample } \\
\text { (interval in } \mathrm{cm} \text { ) }\end{array}$} & \multirow{2}{*}{$\begin{array}{c}\text { Depth } \\
\text { (m) }\end{array}$} & \multirow{2}{*}{$\begin{array}{l}\text { Organic } \\
\text { carbon } \\
\text { (wt.\%) }\end{array}$} & $s_{1}$ & $s_{2}$ & \multirow{2}{*}{$\begin{array}{c}\text { Hydrogen } \\
\text { index }\end{array}$} & \multirow{2}{*}{$\begin{array}{l}\text { Oxygen } \\
\text { index }\end{array}$} & \multirow{2}{*}{$\begin{array}{l}T_{\max } \\
\left({ }^{\circ} \mathrm{C}\right)\end{array}$} & \multirow[b]{2}{*}{$\mathrm{TR}^{\mathrm{c}}$} \\
\hline & & & (mg HC & $\mathrm{C} / \mathrm{g} \mathrm{rk}$ ) & & & & \\
\hline $50-3,0-5$ & 593.50 & 0.06 & & & & & & \\
\hline $59-2,0-5$ & 677.50 & 0.01 & & & & & & \\
\hline $69-3,120-123$ & 775.20 & 0.01 & & & & & & \\
\hline $83-3,120-125$ & 908.20 & 0.01 & & & & & & \\
\hline $89-5,124-150$ & 965.45 & 0.01 & & & & & & \\
\hline $91-2,120-125$ & 978.70 & 0.01 & & & & & & \\
\hline $93-5,120-125$ & 997.20 & 0.18 & & & & & & \\
\hline $95-4,125-130$ & 1013.75 & 0.22 & & & & & & \\
\hline $97-3,125-130$ & 1030.25 & 2.27 & 0.09 & 7.26 & 321 & 51 & 423 & 0.01 \\
\hline $99-5,20-25$ & 1050.20 & 0.22 & & & & & & \\
\hline $101-3,115-120$ & 1066.15 & 0.80 & 0.09 & $0.8 \mathrm{I}$ & 101 & 91 & 409 & 0.10 \\
\hline $103-3,120-125$ & 1084.20 & 1.28 & 0.08 & 2.21 & 173 & 59 & 429 & 0.03 \\
\hline $105-1,110-115$ & 1095.10 & 0.07 & 0.06 & 0.48 & 68 & 80 & 419 & $\mathrm{nr} \mathrm{r}^{\mathrm{d}}$ \\
\hline
\end{tabular}

Note: Blank spaces $=$ not determined. a Milligrams $\mathrm{S}_{2} \mathrm{HC} / \mathrm{g}$ organic carbon.

b Milligrams $\mathrm{CO}_{2} / \mathrm{g}$ organic carbon.

c Transformation ratio: $S_{1} /\left(S_{1}+S_{2}\right)$

d Total hydrocarbon yield is too low for the transformation ratio to be a reliable indicator of maturity.

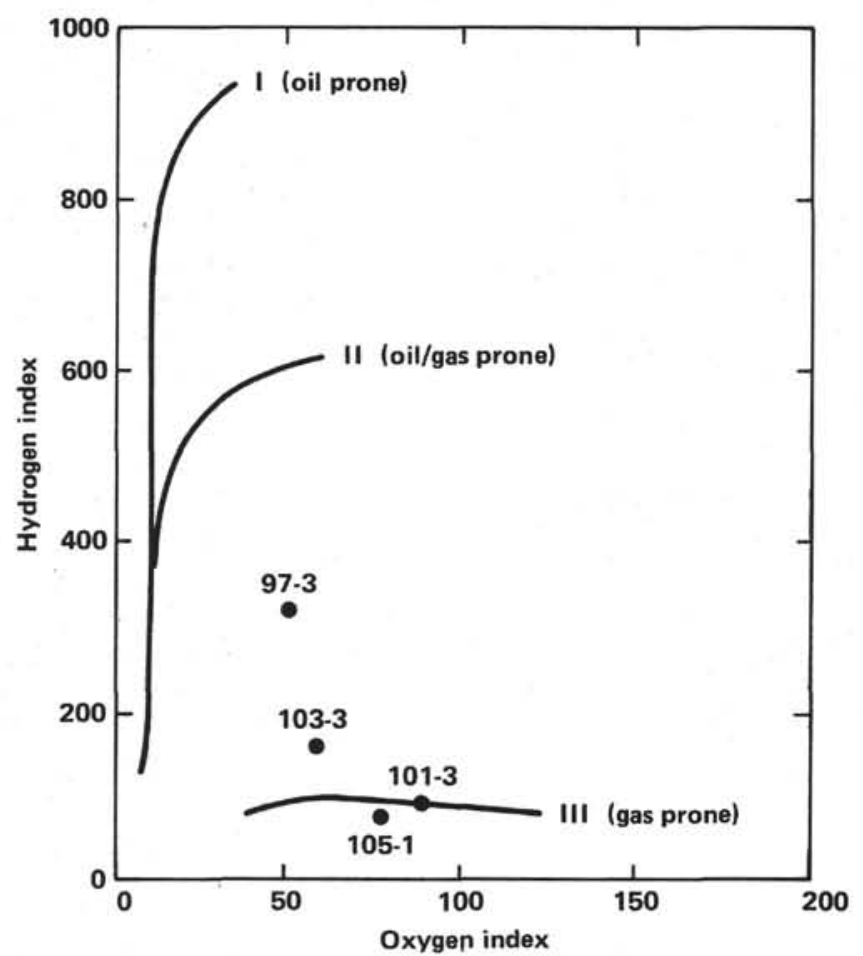

Figure 2. Modified van Krevelen-type diagram utilizing pyrolysis data.

from $<1 \mathrm{mg} \mathrm{HC} / \mathrm{g}$ rock to $>7 \mathrm{mg} \mathrm{HC} / \mathrm{g}$ rock. Tissot and Welte (1978) have classified rocks yielding $>6 \mathrm{mg}$ $\mathrm{HC} / \mathrm{g}$ rock as either good potential or effective source rocks depending upon their degree of thermal evolution. By this criterion, only Section 530A-97-3 could be considered a good potential or effective source rock.

Section 530A-97-3 also appears to be the most oilprone sample based on its position on the modified van Krevelen diagram (Fig. 2) in which the hydrogen index (mg S 2 HC/g Corg) and the oxygen index $\left(\mathrm{mg} \mathrm{CO}_{2} / \mathrm{g}\right.$ $\mathrm{C}_{\text {org }}$ ) are substituted for the atomic $\mathrm{H} / \mathrm{C}$ and $\mathrm{O} / \mathrm{C}$ ratios, respectively. These data suggest that Section 530A97-3 is a mixture of type II and type III kerogens. The remaining three samples analyzed evidently contain predominantly either type III organic matter or marine ma- 
terial which has been severely oxidized. Oxidized marine material is chemically equivalent to type III, terrestrially derived organic matter. Characterization by pyrolysis must be confirmed by other techniques because of the method's sensitivity to both the level of organic enrichment and the mineral matrix (Espitalié et al., 1980; Katz, 1981).

Pyrolysis also provides an indication of the thermal maturity of the organic matter through both $T_{\max }$, the temperature of peak pyrolytic hydrocarbon generation, and the transformation ratio $\left(\mathrm{S}_{1} / \mathrm{S}_{1}+\mathrm{S}_{2}\right.$; TR). The low $T_{\max }$ temperatures $\left(<435^{\circ} \mathrm{C}\right)$ and the low transformation ratios $(<0.1)$ indicate that the samples are immature.

\section{Bitumen Characterization}

Extraction and liquid chromatography were performed on the four samples with above-average organic enrichment (Table 2). The extracted samples contained between $438 \mathrm{ppm}$ and $1173 \mathrm{ppm}$ by weight extractable bitumens. The saturate (paraffins + naphthenes) to aromatic ratios are quite low $(0.42-0.86)$, as are the total extract to organic carbon ratios $(0.05-0.11)$. These low values, and the dominance of nonhydrocarbon compounds (asphaltenes and soluble NSO's; Fig. 3), indicate that the organic matter is thermally immature. These properties, however, are also influenced by the original composition of the organic matter. Marine organic matter is capable of generating more aromatic products than is terrestrial material, which tends to generate "waxy," long-chained n-paraffins. Thus an accurate interpretation is dependent upon an evaluation of all the available data.

The quantities of saturate fractions obtained from these samples were insufficient for reliable gas chromatographic analyses.

\section{Elemental Analysis}

The elemental analysis data are summarized in Table 3 and Figure 4. Of the four samples isolated and analyzed, only two had ash contents sufficiently low for the data to be considered reliable $(<30 \%$; Tissot and Welte, 1978). The $\mathrm{H} / \mathrm{C}$ and $\mathrm{O} / \mathrm{C}$ ratios of the two reliable data sets (Sections 530A-97-3 and 101-3), when plotted on a conventional van Krevelen diagram (Fig. 4), suggest that the organic matter contains significant quantities of marine-derived material. Section 530A-97-3 lies very close to the type II reference curve, whereas Section 530A-101-3 plots between the paths of types II and III. This intermediate composition may result either from variations

Table 2. Summary of extraction data and liquid chromatography, Hole 530A.

\begin{tabular}{lccccccc}
\hline $\begin{array}{c}\text { Sample } \\
\text { (interval in } \mathrm{cm})\end{array}$ & $\begin{array}{c}\text { Depth } \\
(\mathrm{m})\end{array}$ & $\begin{array}{c}\text { Total } \\
\text { extract } \\
(\mathrm{ppm})\end{array}$ & $\begin{array}{c}\text { Saturates } \\
(\%)\end{array}$ & $\begin{array}{c}\text { Aromatics } \\
(\%)\end{array}$ & $\begin{array}{c}\text { Non-HC } \\
(\%)\end{array}$ & TOE/TOC & S/A $^{\mathrm{d}}$ \\
\hline $97-3,125-130$ & 1030.25 & 1173 & 6.4 & 15.4 & 78.2 & 0.05 & 0.42 \\
$101-3,115-120$ & 1066.15 & 867 & 9.1 & 10.6 & 80.3 & 0.11 & 0.86 \\
$103-3,120-125$ & 1084.20 & 740 & 9.6 & 20.6 & 69.8 & 0.06 & 0.47 \\
$105-1,110-115$ & 1095.10 & 438 & 11.4 & 21.5 & 67.1 & 0.06 & 0.53 \\
\hline $\begin{array}{l}\text { a Paraffins + naphthenes. } \\
\text { b Precipitated asphaltenes and NSO compounds. }\end{array}$ \\
c Total organic extract/total organic carbon (by weight). \\
d Paraffins + naphthenes/aromatics.
\end{tabular}

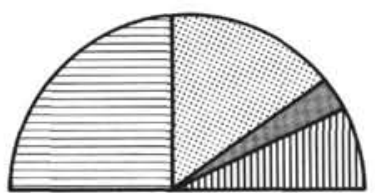

Core 97 , Section 3

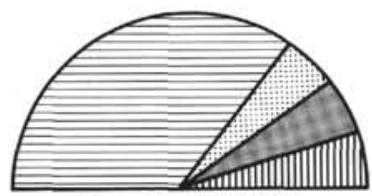

Core 101, Section 3

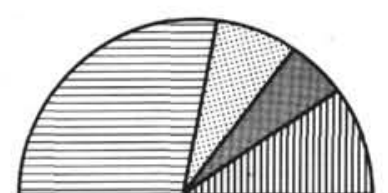

Core 103 , Section 3

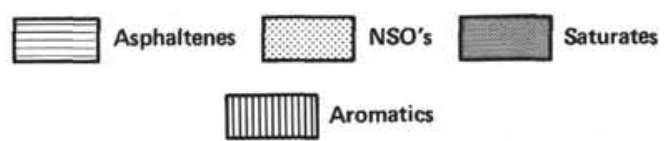

Figure 3. Gross composition of the extracted bitumens, Hole 530A.

Table 3. Elemental composition of kerogen concentrates, Hole 530A.

\begin{tabular}{|c|c|c|c|c|c|c|c|c|}
\hline \multirow{2}{*}{$\begin{array}{c}\text { Sample } \\
\text { (interval in } \mathrm{cm} \text { ) }\end{array}$} & \multirow{2}{*}{$\begin{array}{l}\text { Depth } \\
\text { (m) }\end{array}$} & \multirow{2}{*}{$\begin{array}{l}\text { ASH } \\
(\%)\end{array}$} & \multirow{2}{*}{$\begin{array}{c}\mathrm{H} \\
(\%)\end{array}$} & \multirow{2}{*}{$\underset{(\%)}{C}$} & \multirow{2}{*}{$\underset{(\%)}{O}$} & \multirow{2}{*}{$\underset{(\%)}{N}$} & \multicolumn{2}{|c|}{$\begin{array}{l}\text { Atomic } \\
\text { ratios }\end{array}$} \\
\hline & & & & & & & $\mathrm{H} / \mathrm{C}$ & $\bar{O} / \mathrm{C}$ \\
\hline $97-3,125-130$ & 1030.25 & 5.0 & 6.6 & 63.9 & 9.6 & 2.5 & 1.25 & 0.112 \\
\hline $101-3,115-120$ & 1066.15 & 6.5 & 6.5 & 69.2 & 11.1 & 2.8 & 1.13 & 0.120 \\
\hline $103-3,120-125$ & 1084.20 & 63.1 & a & a & a & a & a & a \\
\hline $105-1,110-115$ & 1095.10 & 38.3 & a & a & a & a & a & a \\
\hline
\end{tabular}

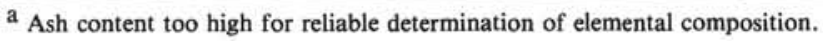

in the level of preservation of marine material or from the input of terrestrial material.

\section{DISCUSSION}

The data suggest that there are strong variations in the extent of organic preservation and/or input within the stratigraphic column. The post-Cenomanian samples of this study were organically lean, suggesting an oxic depositional environment not normally conducive to the preservation of organic matter. Because of their lean nature, no attempt was made to further characterize this material. The Albian and Cenomanian samples were organically richer than the post-Cenomanian group. Section 530A-97-3 (Cenomanian) appears to contain the only clearly defined kerogen of marine origin (i.e., type II). The remaining samples appear to be either partially oxidized marine material or derived in part from higher terrestrial plants.

With the limited stratigraphic sampling and the available geochemical data, one cannot determine whether the characteristics of the organic matter result from oxidation of marine material or from the deposition of higher terrestrial plants. Moreover, it cannot be established whether the black shales represent transient periods of basin stagnation or the expansion and contraction of an oxygen-minimum layer. The presence of black shales does not necessarily imply anoxicity at Site 530. The shales could have originated from organic-rich sediments that had been transported basinward by tur- 


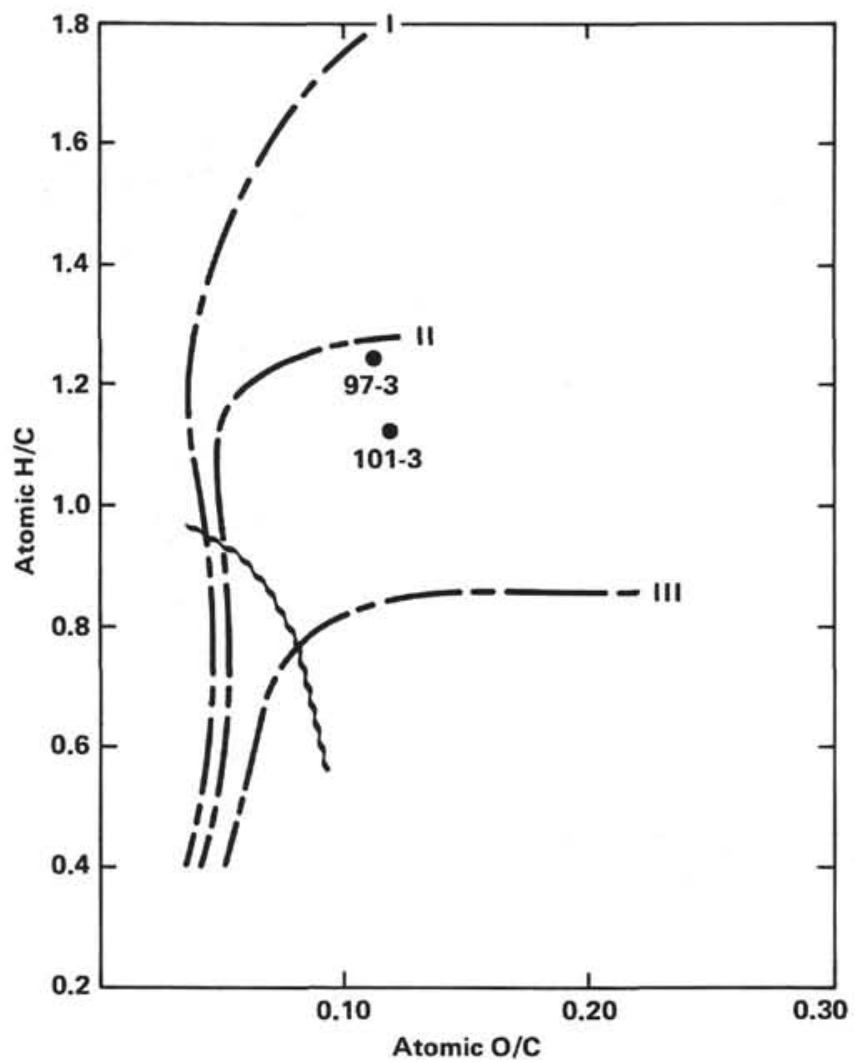

Figure 4. H/C and $\mathrm{O} / \mathrm{C}$ ratios of isolated kerogens plotted on a van Krevelen diagram.

bidity currents from an up-slope position (Dean et al., 1981).

These data and those reported elsewhere in this volume (e.g., Meyers) are generally consistent with those reported earlier for Site 364 (Robert et al., 1979; and Tissot et al., 1980), indicating that within the Angola Basin potential hydrocarbon source facies are limited to the pre-Santonian and upper Tertiary strata. These stratigraphic intervals are not uniformly enriched and show a great deal of variability with respect to their generating potential and the types of products to be expected. These data do, however, suggest that upon the attainment of a sufficient level of thermal maturation, portions of the stratigraphic section could provide for the accumulation of both oil and gas.

\section{ACKNOWLEDGMENTS}

I wish to thank Drs. L. W. Elrod, J. G. Erdman, J. E. Lacey, and E. H. Man for their critical comments, and G. E. Mayfield for his assistance in the preparation of the manuscript. The author acknowledges Texaco Inc.'s permission to publish this paper. Texaco contribution number 2534.

\section{REFERENCES}

Dean, W. E., Barron, E. J., Boyce, R. E., et al., 1981. Cretaceous black-shale deposition within an oxidized red-clay turbidite environment, southern Angola Basin, South Atlantic Ocean. Am. Assoc. Petrol. Geol. Bull., 65:917. (Abstract)

Demaison, G. J., and Moore, G. T., 1980. Anoxic environments and oil source bed genesis. Am. Assoc. Petrol. Geol. Bull., 64: 1179-1209.

Espitalié, J., Laporte, L. J., Madec, M., Marquis, F., Leplat, P. J., and Boutefeu, A., 1977. Methode rapide de caractérisation des roches mères de leur potential petrolier et de leur degré d'évolution. Rev. Inst. Franc. Petrole, 32:32-42.

Espitalie, J., Madec, M., and Tissot, B., 1980. Role of mineral matrix in kerogen pyrolysis: Influence on petroleum generation and migration. Am. Assoc. Pétrol. Geol. Bull., 64:59-66.

Katz, B., 1981. Limitation of Rock-Eval pyrolysis for typing organic matter. Am. Assoc. Petrol. Geol. Bull., 65:944. (Abstract)

McIver, R. D., 1975. Hydrocarbon occurrences from JOIDES Deep Sea Drilling Project cores. Proc. Ninth World Pet. Congr., Tokyo: London (Applied Science Publ.), 2:269-280.

Robert, C., Herbin, J. P., Deroo, G., Giroud d'Argoud, G., and Chamley, H., 1979. L'Atlantique Sud au Crétace d'apres l'étude des minéraux argileux et de la matiere organique (Legs 39 et 40 DSDP). Oceanol. Acta, 2:209-218.

Tissot, B., Demaison, G., Masson, P., Delteil, J. R., and Combaz, A., 1980. Paleoenvironment and petroleum potential of middle Cretaceous black shales in Atlantic basins: Am. Assoc. Petrol. Geol. Bull., 64:2051-2063.

Tissot, B., Deroo, G., and Herbin, J. P., 1979. Organic matter in Cretaceous sediments of the North Atlantic: Contribution to sedimentology and paleogeography. In Talwani, M., Hay, W. W., and Ryan, W. B. F. (Eds.), Deep Drilling Results in the Atlantic Ocean: Continental Margins and Paleoenvironment. Maurice Ewing Ser.: Washington (Am. Geophys. Union), 3:362-374.

Tissot, B., Durand, B., Espitalié., J., and Combaz, A., 1974. Influence of the nature and diagenesis of organic matter in the formation of petroleum. Am. Assoc. Petrol. Geol. Bull., 58:499-506.

Tissot, B., and Welte, D. H., 1978. Petroleum Formation and Occurrence: New York (Springer-Verlag).

Date of Initial Receipt: December 15, 1981 